\title{
Preoperative Airway Obstruction as a Cause of Morbidity in Patients Undergoing Mitral Valve Replacement
}

\section{Mitral Kapak Replasmanı Yapılan Olgularda Bir Morbidite Nedeni Olarak Preoperatif Havayolu Obstrüksiyonu}

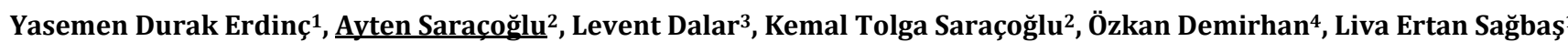

1İstanbul Bilim Üniversitesi Tıp Fakültesi Kardiyovasküler Cerrahi Anabilim Dalı, İstanbul, Türkiye

2İstanbul Bilim Üniversitesi Tıp Fakültesi Anesteziyoloji Ve Reanimasyon Anabilim Dalı, İstanbul, Türkiye

3İstanbul Bilim Üniversitesi Tıp Fakültesi Göğüs Hastalıkları Anabilim Dalı, İstanbul, Türkiye

4İstanbul Bilim Üniversitesi Tıp Fakültesi Göğüs Cerrahisi Anabilim Dalı, İstanbul, Türkiye

\section{$\ddot{O} Z$}

GíRiş ve AMAÇ: Mitral kapak replasmanı hastalarında, preoperatif solunum fonksiyon testleriyle saptanan hava yolu obstruksiyonunun, postoperatif mekanik ventilasyon süresi ve yoğun bakım yatış süresiyle iliş̧kisini araştırmayı amaçladık.

YÖNTEM ve GEREÇLER: Kliniğimizde mitral kapak replasmanı yapılan 62 ardışık hasta, çalışmaya alındı. Cinsiyet, sistemik hastalık varlığl, sigara kullanımı, solunum fonksiyon testleri, ejeksiyon fraksiyonu, pulmoner arter basincl, peroperatif kardiyopulmoner baypas ve aort klempi süreleri, postoperatif entübasyon süresi, cerrahi yoğun bakım süresi, preoperatif ve postoperatif labratuar testleri, arter kan gazı değerleri kaydedildi.

BULGULAR: Hastaların 47 'sine eşlik eden sistemik hastalık mevcuttu. Bunlardan 9'u astım, 8'i kronik obstruktif akciğer hastalı̆̆ı idi. Solunum yolu hastalığı olanlarda yoğun bakım kalış süresi solunum yolu hastalığ olmayanlardan anlaml olarak daha düşüktü $(p<0,05)$. Kronik obstruktif akciğer hastalığı olanlarda yoğun bakım yatış süresi, kronik obstruktif akciğer hastalı̆̆ olmayanlardan anlamlı olarak daha düşüktü $(p<0,05)$. Hastaların yoğun bakım yatış süresi ile renal fonksiyon göstergeleri arasinda anlaml pozitif korelasyon mevcuttu $(p<0,05)$. Entübasyon süresi ile kardiyopulmoner baypas süresi arasında anlamlı pozitif korelasyon bulundu $(p<0,05)$. Entubasyon süresi ile birinci saniyedeki zorlu ekspiratuvar volüm değeri arasında anlamlı negatif korelasyon mevcuttu $(p<0,05)$.

TARTIŞMA ve SONUÇ: Kardiyopulmoner baypas ile mitral kapak replasmanı planlanan hastaların preoperatif dönemde ayrıntılı olarak havayolu obstruksiyonu varlığı açısından değerlendirilmeleri, postoperatif mekanik ventilasyon gereksinimi ve uzayan yatışın azaltılmasını sağlayabilir kanısına varılmıştır.

Anahtar Kelimeler: mitral kapak replasmani, hava yolu obstruksiyonu, morbidite

\begin{abstract}
INTRODUCTION: We aimed to investigate the relationship between preoperative pulmonary function tests detected by obstruction of the airway and postoperative intubation time with prolonged intensive care unit stay in patients undergoing mitral valve replacement.
\end{abstract}

METHODS: Sixty-two consecutive patients undergoing mitral valve replacement surgery were included. Patients' gender, presence of systemic disease, smoking history, pulmonary function tests, ejection fraction, pulmonary artery pressure, perioperative cardiopulmonary bypass and aortic clamp time, postoperative intubation time, length of stay in the intensive care unit, preoperative and postoperative laboratory findings, arterial blood gas values were recorded.

RESULTS: In 47 patients systemic concomitant diseases were diagnosed. Nine had asthma, 8 had chronic obstructive pulmonary disease. Length of stay in the intensive care unit was significantly lower in patients with respirotary disease under treatment than the patients without respirotary disease $(p<0.05)$. Chronic Obstructive Pulmonary Disease patients stayed significantly shorter than non-Chronic Obstructive patients $(p<0.05)$. Significantly positive correlation existed between intensive care staying time and post-operative renal function indicators $(p<0.05)$. Significantly negative correlation existed between intubation period and forced expiratory volume in first second $(p<0.05)$.

DISCUSSION AND CONCLUSION: Preoperative airway obstruction assessments may provide postoperative decreased hospital stay and mechanical ventilation requirement in patients undergoing mitral valve replacement with cardiopulmonary bypass.

Keywords: mitral valve replacement, airway obstruction, morbidity

\footnotetext{
İletisim / Correspondence:

Dr. Ayten Saraçoğlu

İstanbul Bilim Üniversitesi Tip Fakültesi Anesteziyoloji ve Reanimasyon Anabilim Dall, İstanbul, Türkiye

E-mail: anesthesiayten@gmail.com

Başvuru Tarihi: 04.11.2017

Kabul Tarihi:22.01.2018
} 


\section{INTRODUCTION}

Today, cost analyses for coronary artery bypass and valve surgery have gained more importance. Duration of intensive care unit (ICU) and hospital stay of patients is among the main factors determining the cost of treatment. Although patients undergo similar surgical procedures and are monitored in the same unit, the duration of ICU and hospital stay may vary. Concomitant diseases of patients should be carefully evaluated and treated, then the treatment costs of patients who undergo coronary bypass and valve surgery can be reduced (1). It is of primary importance to predefine risk factors that trigger such conditions such as prolonged intubation and ICU stay, which may affect the cost.

Several studies have revealed that as a systemic disease, chronic obstructive pulmonary disease (COPD) is an important risk factor in patients undergoing valve and coronary surgery $(2,3)$. Specified risk scoring methods also indicate that COPD is a risk factor in surgical procedures (4).

It is essential that preoperative risk factors are assessed with additional tests and supported with additional treatments. There may be differences in clinical studies since duration of postoperative intubation and ICU stay in coronary bypass and valve surgery depends on multiple interrelated factors. The aim of the present study is to reveal the relationship between postoperative morbidity and preoperative airway obstruction determined by preoperative assessment in patients undergoing mitral valve replacement, and to present the importance of preoperative assessment.

\section{METHODS}

Following the Ethics Committee approval of our University, we included 62 consecutive patients who underwent mitral valve replacement. We recorded the presence of airway obstruction diagnosed in the preoperative period. All patients' sex, presence of systemic disease and smoking history were recorded. Forced expiratory volume in 1 second (FEV1), forced vital capacity (FVC), FEV1/FVC ratio and mid-expiratory flow (MEF) $25-75 \%$ values were recorded in spirometric measurements (ZAN 100 Pulmonary Spirometer, Colorado, USA). Echocardiography values were performed using GE-VingMed Vivid S5 Echo Doppler Ultrasound. Ejection fraction (EF), systolic pulmonary artery pressure (sPAP), degree of mitral regurgitation (MR) and tricuspid regurgitation (TR) were recorded. Durations of preoperative cardiopulmonary bypass (CPB) and aortic crossclamp (XCL) were recorded. Duration of intubation and length of ICU stay were also recorded. Preoperative and postoperative aspartate aminotransferase (AST), alanine aminotransferase (ALT), blood urea nitrogen (BUN), creatinine and blood gas values $(\mathrm{pH}$, carbon dioxide $(\mathrm{CO} 2)$, oxygen (O2), hematocrit and glucose) were recorded using the Cobas 6000 analyzer series.

Patients who underwent only mitral valve replacement were considered as single-operation patients, while patients who underwent coronary bypass, aortic valve replacement or tricuspid annuloplasty and/or valve replacement in addition to mitral valve replacement were considered as multiple-operation patients.

\section{Statistical Analysis}

Statistical Package for Social Sciences (SPSS) 22.0 (IBM Corp, Armonk, NY, USA) was applied for statistical analysis. Quantitative data was analyzed using the ANOVA, Kruskal-Wallis and Mann-Whitney U tests. The Wilcoxon test was used for repeated measures. Qualitative data analysis was performed with the Chi-square test or the Fischer Test when the Chi-square test conditions could not be met.

\section{RESULTS}

A total of 62 patients undergoing mitral valve replacement were included in the study. Twenty of them underwent combined surgery. The number of female patients were 36 (58.1\%) and 26 (41.9\%) were male. Forty-two patients underwent only mitral valve replacement while 20 had combined surgery. Forty-seven patients (75.8\%) had a concomitant systemic disease. In the preoperative assessment, 9 patients (14.5\%) were diagnosed with asthma and 8 patients (12.9\%) were diagnosed with chronic obstructive pulmonary disease (COPD). Seventeen of all patients (27.7\%) had a history of smoking. Ten $(16.1 \%)$ of the patients were diagnosed with COPD and asthma with a history of medication (Table 1). 


\begin{tabular}{|c|c|c|c|c|c|}
\hline & & \multicolumn{3}{|c|}{ Length of stay in ICU } & \multirow[b]{2}{*}{$\mathrm{p}$} \\
\hline & & $\min -\max$ & $\begin{array}{l}\text { medi } \\
\text { an }\end{array}$ & $\begin{array}{c}\text { mean } \pm s . d \\
.\end{array}$ & \\
\hline \multirow{2}{*}{ Gender } & & $24.0-240.0$ & 45.0 & $50.9 \pm 44.3$ & \multirow{2}{*}{0.946} \\
\hline & Male & $24.0-120.0$ & 37.5 & $49.8 \pm 32.2$ & \\
\hline \multirow{2}{*}{$\begin{array}{l}\text { Number of } \\
\text { operations }\end{array}$} & Single & $24.0-120.0$ & 42.5 & $45.3 \pm 26.5$ & \multirow{2}{*}{0.619} \\
\hline & Multiple & $24.0-240.0$ & 42.5 & $61.2 \pm 57.3$ & \\
\hline \multirow{2}{*}{$\begin{array}{l}\text { Respiratory } \\
\text { disease }\end{array}$} & & $24.0-110.0$ & 24.0 & $35.2 \pm 27.3$ & \multirow{2}{*}{0.016} \\
\hline & No & $24.0-240.0$ & 48.0 & $54.1 \pm 41.1$ & \\
\hline \multirow{2}{*}{ Smoking } & Yes & 24.0-120.0 & 34.0 & $42.4 \pm 25.7$ & \multirow{2}{*}{0.466} \\
\hline & No & $24.0-240.0$ & 45.0 & $53.5 \pm 43.3$ & \\
\hline \multirow{2}{*}{ Asthma } & Yes & $24.0-110.0$ & 24.0 & $38.9 \pm 31.0$ & \multirow{2}{*}{0.111} \\
\hline & No & $24.0-240.0$ & 48.0 & $52.4 \pm 40.5$ & \\
\hline \multirow{2}{*}{ COPD } & Yes & $24.0-72.0$ & 24.0 & $30.0 \pm 17.0$ & \multirow{2}{*}{0.024} \\
\hline & No & $24.0-240.0$ & 48.0 & $53.5 \pm 40.9$ & \\
\hline \multirow{2}{*}{ Drug use } & Yes & $24.0-110.0$ & 24.0 & $32.6 \pm 27.2$ & \multirow{2}{*}{0.009} \\
\hline & No & $24.0-240.0$ & 48.0 & $53.9 \pm 40.6$ & \\
\hline \multirow{2}{*}{$\begin{array}{l}\text { Systemic } \\
\text { disease }\end{array}$} & Yes & $24.0-240.0$ & 48.0 & $54.7 \pm 43.2$ & \multirow{2}{*}{0.165} \\
\hline & No & $24.0-95.0$ & 24.0 & $37.1 \pm 19.4$ & \\
\hline \multicolumn{6}{|c|}{$\begin{array}{l}\text { Mann Whitney U test } \\
\text { ICU: intensive care uni } \\
\text { COPD: Chronic obstruc }\end{array}$} \\
\hline
\end{tabular}

The mean preoperative FEV1 values of patients were $2.5 \pm 0.8$ (range 1-4.4). The mean FEV1 as percentage was $83.4 \% \pm 16.6$ (range 55-117). The mean FVC values were $2.9 \pm 0.9$ (range 1.3-5.2). The mean FVC as percentage was $83.6 \% \pm 16.1$ (range 51-118). The mean FEV1/FVC ratio was $91 \pm 15.1$ (range 66-134). The mean preoperative EF was $52.9 \pm 8.6 \%$, with a minimum value of $29 \%$ and a maximum value of $68 \%$. The mean degree of mitral regurgitation was $3.2 \pm 0.9$ and the mean tricuspid regurgitation degree was $2.4 \pm 0.8$. The mean sPAP was $49 \pm 13.6$, with a minimum value of 18 and a maximum value of 90 . The mean cardiopulmonary bypass time was $123.9 \pm 53.2 \mathrm{~min}$ and the mean aortic cross-clamp period was $84.5 \pm 37.4 \mathrm{~min}$.

The mean value of BUN was recorded as $18.9 \pm 9.9 \mathrm{mg}$ dL-1, mean creatinine level was $1.1 \pm 1.5 \mathrm{mg}$ dL-1, mean AST was $23.9 \pm 14.1 \mathrm{U} \mathrm{L}-1$, mean ALT was $21.8 \pm 16.8 \mathrm{U}$ L-1, mean hematocrit was $38 \pm 4.5 \%$, mean $\mathrm{Ph}$ was $7.4 \pm 0.1$, mean $\mathrm{CO} 2$ was $36.1 \pm 5.2 \mathrm{mmHg}$, mean $\mathrm{O} 2$ was $193 \pm 68 \mathrm{mmHg}$ and the mean glucose level was $113.2 \pm 22.9 \mathrm{mg} \mathrm{dL}^{-1}$

The duration of intubation did not show any significant difference between male and female patients ( $p>0.05)$, as well as between the singleoperation and multiple-operation patients $(\mathrm{p}>0.05)$, between patients with respiratory tract disease and those without ( $p>0.05$ ), between smoking and nonsmoking patients $(p>0.05)$, between patients with asthma and those without ( $>0.05)$, between patients with COPD and those without $(p>0.05)$, between patients with a history of medication and those without ( $p>0.05)$, and lastly between patients with systemic disease and those without $(p>0.05)$ (Table 2).

\begin{tabular}{|c|c|c|c|c|c|}
\hline & & Dura & ion of Int & ation & \\
\hline & & $\begin{array}{l}\min - \\
\max \end{array}$ & median & $\begin{array}{l}\text { Mean } \\
\pm \text { s.d. }\end{array}$ & $p$ \\
\hline \multirow{2}{*}{ Gender } & Female & $4.0-50.0$ & 9.0 & $10.4 \pm 7.5$ & \multirow{2}{*}{0.636} \\
\hline & Male & $3.0-86.0$ & 8.5 & $11.7 \pm 15.7$ & \\
\hline \multirow{2}{*}{$\begin{array}{l}\text { Number of } \\
\text { operations }\end{array}$} & Single & $3.0-86.0$ & 9.0 & $10.9 \pm 12.4$ & \multirow{2}{*}{0.826} \\
\hline & Multiple & $4.0-50.0$ & 9.0 & $11.1 \pm 9.7$ & \\
\hline \multirow{2}{*}{$\begin{array}{l}\text { Respiratory } \\
\text { disease }\end{array}$} & Yes & $4.0-16.0$ & 9.0 & $10.1 \pm 3.4$ & \multirow{2}{*}{0.325} \\
\hline & No & $3.0-86.0$ & 8.5 & $11.1 \pm 12.8$ & \\
\hline \multirow{2}{*}{ Smoking } & Yes & $3.0-86.0$ & 9.0 & $13.6 \pm 19.0$ & \multirow{2}{*}{0.924} \\
\hline & No & $3.0-50.0$ & 9.0 & $9.9 \pm 7.1$ & \\
\hline \multirow{2}{*}{ Asthma } & Yes & $4.0-16.0$ & 9.0 & $10.2 \pm 3.9$ & \multirow{2}{*}{0.393} \\
\hline & No & $3.0-86.0$ & 9.0 & $11.1 \pm 12.4$ & \\
\hline \multirow{2}{*}{ COPD } & Yes & $4.0-15.0$ & 10.5 & $10.0 \pm 3.4$ & \multirow{2}{*}{0.425} \\
\hline & No & $3.0-86.0$ & 9.0 & $11.1 \pm 12.3$ & \\
\hline \multirow{2}{*}{ Drug use } & Yes & $4.0-16.0$ & 9.0 & $10.2 \pm 3.6$ & \multirow{2}{*}{0.327} \\
\hline & No & $3.0-86.0$ & 8.5 & $11.1 \pm 12.5$ & \\
\hline \multirow{2}{*}{$\begin{array}{l}\text { Systemic } \\
\text { disease }\end{array}$} & Yes & $4.0-86.0$ & 9.0 & $11.9 \pm 13.0$ & \multirow[b]{2}{*}{0.113} \\
\hline & No & $3.0-17.0$ & 7.0 & $8.0 \pm 4.2$ & \\
\hline
\end{tabular}

The duration of ICU stay did not show any significant difference between male and female patients $(p>0.05)$, as well as between the singleoperation and multiple-operation patients $(p>0.05)$. The duration of ICU stay was significantly shorter in patients with respiratory tract disease than in patients without the disease $(p<0.05)$. The duration of ICU stay did not show any significant difference between smoking and non-smoking patients as well as between patients with asthma and those without the disease $(p>0.05)$. However, the duration of ICU stay was significantly shorter in patients with COPD than in patients without the disease $(\mathrm{p}<0.05)$. The duration of ICU stay was also significantly shorter in patients with a history of medication than in patients without a history of medication $(p<0.05)$. 
The duration of ICU stay did not show any significant difference between patients with systemic disease and those without $(\mathrm{p}>0.05)$ (Table $3)$.

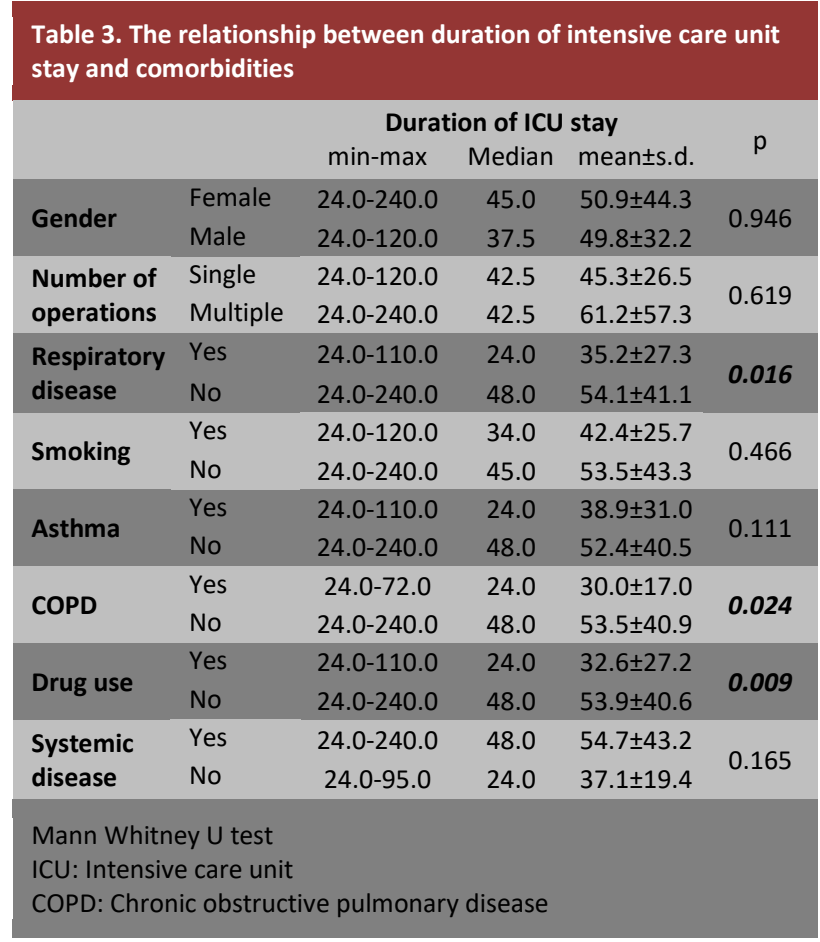

There was a significant positive correlation between the duration of ICU stay and postoperative BUN value and postoperative creatinine value $(p<0.05)$. No significant positive correlation was found between the duration of ICU stay and CPB, XCL, FEV1\%, FVC\%, FVC, FEV1/FVC, MEF\%, MEF, EF, PAP, mitral regurgitation, tricuspid regurgitation, $\mathrm{CO} 2, \mathrm{O} 2$, glucose, $\mathrm{Ph}$, preoperative BUN, preoperative creatinine, preoperativepostoperative hematocrit, preoperativepostoperative ALT, and preoperative-postoperative AST values ( $>0.05$ ) (Table 4).

There was a significant positive correlation between the duration of intubation and CPB time, preoperative-postoperative BUN, and postoperative creatinine level $(p<0.05)$. There was a significant negative correlation between the duration of intubation and FEV1 value $(\mathrm{p}<0.05)$. No significant positive correlation was found between the duration of intubation and XCL, FEV1\%, FVC\%, FVC, FEV1/FVC, MEF\%, MEF, EF, sPAP, mitral regurgitation, tricuspid regurgitation, $\mathrm{CO} 2, \mathrm{O} 2$, glucose, $\mathrm{Ph}$, preoperative creatinine, preoperativepostoperative hematocrit, preoperativepostoperative ALT, and preoperative-postoperative AST values ( $p>0.05$ ) (Table 4).

Table 4. Correlation analyzes for Duration of Intubation and Length of stay in intensive care unit

\begin{tabular}{|c|c|c|c|c|c|c|c|c|}
\hline & & $\begin{array}{c}\text { CPB } \\
\text { time }\end{array}$ & ACC time & FEV1 \% & FEV1 & FVC \% & FVC & $\begin{array}{c}\text { FEV1/ } \\
\text { FVC }\end{array}$ \\
\hline \multirow{2}{*}{$\begin{array}{l}\text { Duration of } \\
\text { Intubation }\end{array}$} & $r$ & 0.258 & 0.208 & -0.151 & -0.262 & -0.078 & -0.199 & 0.239 \\
\hline & $p$ & 0.043 & 0.105 & 0.245 & 0.047 & 0.552 & 0.130 & 0.063 \\
\hline \multirow{3}{*}{$\begin{array}{l}\text { Length of } \\
\text { stay in ICU }\end{array}$} & $r$ & 0.199 & 0.077 & -0.052 & -0.086 & -0.043 & -0.169 & -0.203 \\
\hline & $p$ & 0.121 & 0.550 & 0.693 & 0.519 & 0.743 & 0.199 & 0.116 \\
\hline & & MEF \% & MEF & $\mathrm{EF}$ & PAP & $\mathrm{MR}$ & TR & $\mathrm{pCO}_{2}$ \\
\hline \multirow{2}{*}{$\begin{array}{l}\text { Duration of } \\
\text { Intubation }\end{array}$} & $r$ & -0.122 & -0.240 & -0.152 & -0.096 & -0.002 & 0.008 & -0.131 \\
\hline & $p$ & 0.358 & 0.100 & 0.238 & 0.466 & 0.986 & 0.950 & 0.312 \\
\hline \multirow{3}{*}{$\begin{array}{l}\text { Length of } \\
\text { stay in ICU }\end{array}$} & $r$ & -0.029 & -0.030 & -0.146 & -0.056 & 0.134 & -0.004 & -0.179 \\
\hline & $p$ & 0.828 & 0.838 & 0.258 & 0.670 & 0.298 & 0.975 & 0.163 \\
\hline & & $\mathrm{pO}_{2}$ & Glucose & Ph & $\begin{array}{l}\text { Preop } \\
\text { BUN }\end{array}$ & $\begin{array}{c}\text { Postop } \\
\text { BUN }\end{array}$ & $\begin{array}{c}\text { Preop } \\
\text { Cre }\end{array}$ & $\begin{array}{c}\text { Preop } \\
\text { Cre }\end{array}$ \\
\hline \multirow{2}{*}{$\begin{array}{l}\text { Duration of } \\
\text { Intubation }\end{array}$} & $r$ & -0.033 & 0.145 & 0.232 & 0.298 & 0.313 & 0.133 & 0.335 \\
\hline & $p$ & 0.798 & 0.261 & 0.069 & 0.018 & 0.013 & 0.304 & 0.008 \\
\hline \multirow{3}{*}{$\begin{array}{l}\text { Length of } \\
\text { stay in ICU }\end{array}$} & $r$ & -0.109 & 0.102 & 0.141 & 0.248 & 0.485 & 0.222 & 0.429 \\
\hline & $p$ & 0.401 & 0.428 & 0.273 & 0.052 & 0.000 & 0.083 & 0.000 \\
\hline & & $\begin{array}{l}\text { Preop } \\
\text { Htc }\end{array}$ & $\begin{array}{c}\text { Postop } \\
\text { Htc }\end{array}$ & $\begin{array}{c}\text { Preop } \\
\text { ALT }\end{array}$ & $\begin{array}{c}\text { Postop } \\
\text { ALT }\end{array}$ & $\begin{array}{c}\text { Preop } \\
\text { AST }\end{array}$ & $\begin{array}{c}\text { Postop } \\
\text { AST }\end{array}$ & \\
\hline \multirow{2}{*}{$\begin{array}{l}\text { Duration of } \\
\text { Intubation }\end{array}$} & $r$ & -0.112 & -0.234 & -0.166 & -0.052 & -0.104 & 0.069 & \\
\hline & $p$ & 0.385 & 0.067 & 0.198 & 0.690 & 0.422 & 0.595 & \\
\hline \multirow{2}{*}{$\begin{array}{l}\text { Length of } \\
\text { stay in ICU }\end{array}$} & $r$ & -0.122 & -0.124 & -0.111 & 0.045 & 0.028 & 0.178 & \\
\hline & $p$ & 0.344 & 0.336 & 0.392 & 0.727 & 0.832 & 0.166 & \\
\hline \multicolumn{9}{|c|}{$\begin{array}{l}\text { Spearman Correlation , ICU: Intensive care unit, } \\
\text { CPB: Cardiopulmonary bypass, ACC: Aortic cross-clamp, } \\
\text { FEV: Forced expiratory volume, FVC: Forced vital capacity, } \\
\text { MEF: Mid-expiratory flow, EF: Ejection fraction } \\
\text { PAP: Pulmonary artery pressure, } \\
\text { MR: Mitral regurgitation, Preop: Preoperative, Postop: Postoperative, } \\
\text { Cre: Creaitinine TR: Tricuspid regurgitation }\end{array}$} \\
\hline
\end{tabular}

The postoperative ALT value did not show a significant change compared to the preoperative period ( $p>0.05)$, while the postoperative AST value showed a significant change compared to the preoperative period $(\mathrm{p}<0.05)$. The postoperative BUN value did not show a significant change compared to the preoperative period ( $p>0.05)$. The postoperative creatinine value showed a significant increase compared to the preoperative period $(\mathrm{p}<0.05)$. 
The postoperative hematocrit value also showed a significant increase compared to the preoperative period $(\mathrm{p}<0.05)$ (Table 5).

\section{DISCUSSION}

There are still serious problems in the prevention of complications despite the developments in cardiac surgery and its follow-up care. Complications appear to depend on many pre-, intra-, and postoperative variables. Besides the risk factors depending on multiple variables, it is also a major problem that results are not specific to present complications. As a result, it seems not possible to draw a certain way in the prevention of complications.

Several complications occur during mitral valve and other cardiac surgeries. This is associated with several variables such as the etiology of the disease, the presence of concomitant systemic diseases, surgical technique, cardiopulmonary bypass time and intensive care given in the postoperative period. Common postoperative complications involve hemorrhage, ischemic heart damage, intracranial ischemic injury and cardiac tamponade as well as renal, pulmonary and gastrointestinal problems.

\begin{tabular}{|c|c|c|c|c|c|}
\hline & & $\min -\max$ & median & mean \pm s.d. & $P$ \\
\hline \multirow{2}{*}{ ALT } & Preop & $5.0-120.0$ & 18.0 & $21.8 \pm 16.8$ & \multirow{2}{*}{0.318} \\
\hline & Postop & $6.0-64.0$ & 17.0 & $19.4 \pm 11.1$ & \\
\hline \multirow[b]{2}{*}{ AST } & Preop & $10.0-74.0$ & 20.0 & $23.9 \pm 14.1$ & \multirow[b]{2}{*}{0.000} \\
\hline & Postop & $\begin{array}{l}26.0- \\
179.0\end{array}$ & 50.5 & $60.0 \pm 28.3$ & \\
\hline \multirow{2}{*}{ BUN } & Preop & $7.0-73.0$ & 16.0 & $18.9 \pm 9.9$ & \multirow{2}{*}{0.904} \\
\hline & Postop & $8.0-55.0$ & 16.5 & $19.0 \pm 10.1$ & \\
\hline \multirow{2}{*}{ Creatinine } & Preop & $0.5-12.2$ & 0.9 & $1.1 \pm 1.5$ & \multirow{2}{*}{0.003} \\
\hline & Postop & $0.6-9.3$ & 1.0 & $1.2 \pm 1.2$ & \\
\hline \multirow{2}{*}{ Htc } & Preop & $27.2-48.0$ & 37.8 & $38.0 \pm 4.5$ & \multirow{2}{*}{0.000} \\
\hline & Postop & $26.6-40.6$ & 32.0 & $32.3 \pm 3.3$ & \\
\hline \multicolumn{6}{|c|}{ Wilcoxon test } \\
\hline \multicolumn{6}{|c|}{ Preop: Preoperative, Postop; Postoperative } \\
\hline \multicolumn{6}{|c|}{ ALT: Alanine aminotransferase } \\
\hline \multicolumn{6}{|c|}{ AST: Aspartate aminotransferase } \\
\hline \multicolumn{6}{|c|}{ BUN: Blood urea nitrogen } \\
\hline \multicolumn{6}{|c|}{ Htc: Hematocrit } \\
\hline
\end{tabular}

It is of vital importance to ensure adequate renal function during cardiac surgery. Coffin et al. (5) revealed the serious correlation between the perioperative mortality and renal failure. Antunes et al. (6) concluded that postoperative renal dysfunction led to a dramatic increase in mortality, morbidity and hospitalization time after coronary artery bypass grafting (CABG). The present study also yielded a significant positive correlation between the duration of ICU stay and postoperative renal dysfunction indicators. The postoperative creatinine value showed a significant increase compared to the preoperative period.

Mitral valve surgery represents a high-risk surgical group in terms of pulmonary complications. Significant deficiency may occur in pulmonary functions due to surgical intervention, median sternotomy, effects of anesthesia and cardiopulmonary bypass (7). Furthermore, in the preoperative period, pulmonary functional alterations secondary to the elevated left atrial pressure in mitral valve disease also have a negative impact on postoperative pulmonary function. Preexisting diseases such as COPD are also primary factors that lead to postoperative pulmonary dysfunction and thus prolonged mechanical ventilation and hospital stay. In previous studies it was indicated that a low preoperative FEV1 and duration of anesthesia longer than 2 hours are among factors that increase complications in such patients $(8,9)$.

Today, durations of both intubation and ICU stay have decreased thanks to advanced anesthesia techniques, postoperative intensive care and treatment methods. Accordingly, it is of great importance for early ambulation to carefully evaluate patients in terms of prolonged intubation and prolonged length of ICU stay, and to take necessary measures in the preoperative assessment. Prolonged mechanical ventilation and prolonged ICU stay not only affect morbidity but also increase economic burden and prevent the use of equipment. Thus, it seems critical to monitor more closely patients with risk factors such as COPD and to take measures in the preoperative period in order to shorten the duration of mechanical ventilation and ICU stay. Short-term pulmonary care administered to patients prior to major surgical interventions has been reported to have better outcomes in the postoperative period $(10,11)$. In the present study, the duration of ICU stay was found significantly shorter in patients diagnosed with COPD than in those not diagnosed. We believe that detailed 
preoperative assessment of patients with COPD and advance understanding of the factors that may affect the length of hospital stay as well as preoperative measures can enable shorter postoperative ICU stay and early discharge. It seems helpful in the preoperative period to identify the high-risk group of patients (as their ICU and hospital stay may be affected by postoperative pulmonary reasons), to prepare a personal care plan, and to arrange the use of sources of health care facilities. Similarly, knowing in advance other factors that may extend the duration of hospital stay can help to intensify studies on preventable risk factors and to shorten the duration of hospital stay. Prolonged intubation and ICU stay increase not only hospital costs but also mortality and morbidity rates (12-14). In our study, a significant negative correlation was also found between FEV1 and duration of intubation in patients who underwent mitral valve surgery.

As in all cardiopulmonary bypass surgeries, in mitral valve surgery, there are some changes in the lungs. Due to preoperative pulmonary adverse effects in patients with mitral valve disease, pulmonary dysfunction can be much triggered by the effects of cardiopulmonary bypass. Within the first postoperative 48 hours, there may be decreased compliance based on the fluid extravasation in the lungs, and reversible pulmonary dysfunction. The effects of cardiopulmonary bypass on pulmonary functions occur with the activation of the complement system. Activated neutrophils increase the pulmonary vascular permeability and lead to the development of pulmonary edema. Atelectasis develops as a result of changes in the alveolar surfactant composition and less effective alveolar stability, and atelectasis maintains its effectiveness over the first 48 hours after CPB. Functional residual volume and pulmonary compliance are reduced. An increase appears in the physiological shunts and alveolar-arterial oxygen difference (15). The decrease in cardiopulmonary compliance is directly proportional to the bypass time (16). Cislaghi et al. (17) indicated that prolonged cardiopulmonary bypass time (over 91 minutes) was an independent predictor of prolonged mechanical ventilation. Our study also showed that there was a significant positive correlation between the cardiopulmonary bypass time and the duration of intubation.

Prolonged durations of intubation and ICU stay after mitral valve surgery are associated with increased morbidity, mortality and hospital costs. The results of our study indicated that the duration of ICU stay was shorter in patients with COPD and those with a history of medication. As these patients were supported with prophylactic treatment and their preoperative pulmonary functions were evaluated in detail, it was resulted in better postoperative pulmonary outcomes, shortened ICU stay and decreased mortality.

In our study, a high FEV1 was identified as a valuable parameter for determining postoperative morbidity. The duration of ICU stay was shortened in COPD patients with airway obstruction as a result of the preoperative assessment and treatment. Awareness of the disease was found together with positive outcomes with respect to postoperative morbidity.

\section{LIMITATIONS}

There are some limitations of the current study. First of all this is a retrospective study and we did not have a control group. Therefore future prospective controlled trials are needed. Before the study a detailed pulmonary function analyze should be done using body plethysmography.

\section{CONCLUSION}

Considering patients who have been scheduled for mitral valve replacement, preoperative measures are regarded to be important factors in determining postoperative morbidity especially in patients with a low FEV1 value in the preoperative spirometric evaluation and those diagnosed with COPD. The impact of postoperative complications on morbidity and mortality can be minimized through preoperative assessment that helps to predict postoperative complications.

Preoperative pulmonary regime should be followed in COPD patients for the purpose of optimal lung function and minimal airway secretion. This regime entails smoking cessation, intense inhaled bronchodilator administration, and the use of oral antibiotic in patients with purulent secretions and cough. In preoperative period, patients should be taught how to work with a 
breathing exercise machine as well as coughing and breathing techniques. Patients with a significant bronchospastic component should be given a shortterm treatment with oral corticosteroids. We concluded that such simple and cost effective methods can significantly reduce the incidence of postoperative pulmonary complications.

\section{Acknowledgements:}

This study was not supported by any institution or company.

\section{Conflict of interest:}

None declared.

\section{REFERENCES}

1. Davarpasand T, Hosseinsabet A, Jalali A. Concomitant coronary artery bypass graft and aortic and mitral valve replacement for rheumatic heart disease: short- and mid-term outcomes. Interact Cardiovasc Thorac Surg 2015; 21:322-8.

2. Najafi M, Sheikhvatan M, Mortazavi SH. Do preoperative pulmonary function indices predict morbidity after coronary artery bypass surgery? Ann Card Anaesth 2015; 18:293-8.

3. Cingoz F, Oz BS, Arslan G, et al. Is chronic obstructive pulmonary disease a risk factor for epistaxis after coronary artery bypass graft surgery? Cardiovasc J Afr 2014; 25:279-81.

4. Smetana GW, Pfeifer KJ, Slawski BA, et al. Risk factors for postoperative pulmonary complications: an update of the literature. Hosp Pract (1995) 2014; 42:126-31.

5. Coffin ST, Waguespack DR, Haglund NA, et al. Kidney dysfunction and left ventricular assist device support: a comprehensive perioperative review. Cardiorenal Med 2015; 5:48-60.

6. Antunes PE, Prieto D, Ferrao de OJ, et al. Renal dysfunction alter myocardial revascularization. Eur Cardiothorac Surg 2004; 25:597-604.

7. Saxena P, Luthra S, Dhaliwal RS, et al. Early changes in pulmonary functions after mitral valve replacement. Ann Thorac Med 2007; 2:111-7.

8. Maddali MM. Chronic obstructive lung disease: Perioperative management. Middle East J Anesthesiol 2008; 19:1219-39.
9. Licker M, Schweizer A, Ellenberger C, et al. Perioperative medical management of patients with COPD. Int J Chron Obstruct Pulmon Dis 2007; 2:493-515.

10. Lindenauer PK, Stefan MS, Shieh MS, et al. Outcomes associated with invasive and noninvasive ventilation among patients hospitalized with exacerbations of chronic obstructive pulmonary disease. JAMA Intern Med 2014; 174:1982-93.

11. Quintana JM, Esteban C, Unzurrunzaga A, et al; IRYSS-COPD group. Predictive score for mortality in patients with COPD exacerbations attending hospital emergency departments. BMC Med 2014; 12:66.

12. Siddiqui UT, Tahir MZ, Shamim MS, et al. Clinical outcome and cost effectiveness of early tracheostomy in isolated severe head injury patients. Surg Neurol Int 2015; 6:65.

13. Tsai WH, Hsu HC, Shih $\mathrm{CH}$. Increased risks of endotracheal tube cuff colonization after prolonged intubation. Chin J Physiol 2014; 57:1527.

14. Liu CC, Livingstone D, Dixon E, et al. Early versus late tracheostomy: a systematic review and meta-analysis. Otolaryngol Head Neck Surg 2015; 152:219-27.

15. Whiting D, Yuki K, DiNardo JA. Cardiopulmonary bypass in the pediatric population. Best Pract Res Clin Anaesthesiol 2015; 29:241-56.

16. Roosens C, Heerman J, De Somer F, et al. Effects of off-pump coronary surgery on the mechanics of the respiratory system, lung, and chest wall: Comparison with extracorporeal circulation. Crit Care Med 2002; 30:2430-7.

17. Cislaghi F, Condemi AM, Corona A. Predictors of prolonged mechanical ventilation in a cohort of 3269 CABG patients. Minerva Anestesiol 2007; 73:615-21. 